\title{
Two new Mediterranean Stenothoe (Crustacea, Amphipoda) from the coast of Israel
}

\author{
TRAUDL KRAPP-SCHICKEL ${ }^{1}$ AND SABRINA LO BRUTTO ${ }^{2}$ \\ ${ }^{1}$ Forschungsmuseum A. Koenig, Adenauerallee 160, D-53113 Bonn, Germany, ${ }^{2}$ Department of Sciences and Biological Chemical and \\ Pharmaceutical Technologies, Section of Animal Biology, University of Palermo, Via Archirafi 18, 90123 Palermo, Italy
}

Within collections along the Mediterranean coast of Israel, two new species of Stenothoe (Amphipoda) were found. They were found to be living on sand or mud and probably licking the surface of grains.

Keywords: Amphipods, Stenothoidae, Stenothoe bella sp. nov., Stenothoe levantina sp. nov. Israel, Mediterranean

Submitted 9 March 2015; accepted 10 May 2015

\section{INTRDDUCTION}

Collections organized by the Israel National Institute of Oceanography during the years 2012-2015 (project by Bella Galil, from off Ashdod, Mediterranean coast) and sorted by members of the Section of Animal Biology, Department of STeBiCeF, University of Palermo, Italy, presented, among others, two new species of the amphipod genus Stenothoe. This genus is reviewed by Krapp-Schickel (2015) - 55 species are known to belong to this genus world-wide. Within the Mediterranean region, five species belong to the group of species that have telson lacking spines, while nine species are known having a spinose telson. Two new members of the latter group are described here.

\section{MATERIAL AND METHDDS}

Material was collected by Bella Galil (Tel Aviv, Israel) and stored in the University of Palermo (Italy). In the course of surveys of the shallow soft bottoms along the Mediterranean coast of Israel, sediment samples were taken with a $32 \times$ $35 \mathrm{~cm}$ Van-Veen grab (KAHLSICO, model WA265/SS214), volume $20 \mathrm{l}$, penetrating up to $20 \mathrm{~cm}$ into the substrate. They were then preserved in $70 \%$ alcohol and, within days of collection, sieved on a $250 \mathrm{~mm}$ mesh.

The amphipods were studied and dissected in temporary glycerine slides, preparations were made in Faure's fluid and studied under various light microscopes. Pencil drawings were scanned in and 'inked' by applying the software Adobe Illustrator $\mathrm{CS}_{3}$ and Wacom tablets $\mathrm{A}_{4}$ and $\mathrm{A}_{5}$. The examined specimens are deposited, together with archival organic DNA, in the Zoological Museum of the University of Palermo, Italy (MZPA).

Corresponding author:

T. Krapp-Schickel

Email: traudl.krapp@uni-bonn.de
The following acronyms are used in the morphological descriptions: $\mathrm{A} 1,2=$ antennae; art $=$ articles, $\mathrm{Cx}=$ coxal plate; $\mathrm{Ep}=$ epimeral plate; flag = flagellum; Gn1, $2=$ gnathopods; $\mathrm{Md}=$ mandible; $\mathrm{Mx} 1,2=$ maxillae; $\mathrm{Mxp}=$ maxilliped; $\mathrm{P}_{3}-$ $7=$ peraeopods; ped $=$ peduncle; $\mathrm{T}=$ telson; $\mathrm{U}_{1-3}=$ uropods.

In this paper, the following morphological terms are applied in the same way as in most of the earlier publications by the first author (see also Krapp-Schickel, 2011: 2): tooth = non-articulated pointed ectodermal projection; spine $=$ stout (narrowly conical), articulated structure (synonymous to 'robust seta' of Watling, 1989); seta = slender, flexible articulated hair-like structure.

\section{SYSTEMATICS}

Class MALACOSTRACA Latreille, 1802

Suborder GAMMARIDEA Latreille, 1802

Order AMPHIPODA Latreille, 1816

Family STENOTHOIDAE Boeck, 1871

Genus Stenothoe Dana, 1852

Stenothoe bella sp. nov.

Figures 1-3

\section{MATERIAL EXAMINED}

Holotype: male, from sample VM 49 (A) Via Maris $31^{\circ} 51.1866^{\prime} \mathrm{N} 34^{\circ} 41.0671^{\prime} \mathrm{E}, 6$ June 2015; $20.17 \mathrm{~m}$ depth; in alcohol. Holotype male and additional material in Faure coded as MZPA-AMPH-H_ooo6.

\section{ADDITIONAL MATERIAL}

One specimen from sample SB6 (C) Hani $31^{\circ} 49.0876^{\prime} \mathrm{N}$ $34^{\circ} 33.3381^{\prime} \mathrm{E}$; May 2013; $37.34 \mathrm{~m}$ depth, in alcohol + glycerine.

One juvenile specimen from sample SB 18(A) $31^{\circ} 44.8272^{\prime} \mathrm{N} 34^{\circ} 33.0664^{\prime} \mathrm{E}$; May 2014; $20.37 \mathrm{~m}$ depth, in alcohol + glycerine.

One juvenile from sample VM 44(A) Via Maris $31^{\circ} 56.1802^{\prime} \mathrm{N} 34^{\circ} 41.0255^{\prime} \mathrm{E}$; 6 June $2013 ; 17.98 \mathrm{~m}$ depth; in alcohol + glycerine. 




Fig. 1. Stenothoe bella sp. nov.: head with antennae A1, A2 and gnathopods; $\mathrm{Md}=$ mandible; Gn1, Gn2 = gnathopods 1, 2.

One specimen from sample 46 (C) Via Maris $31^{\circ} 56.1834^{\prime} \mathrm{N}$ $34^{\circ} 40.7737^{\prime} \mathrm{E} ; 5$ May 2014; $25.2 \mathrm{~m}$ depth; in alcohol + glycerine.

One specimen from sample 40 (A) Via Maris $31^{\circ} 51.1866^{\prime} \mathrm{N}$ $34^{\circ} 41.0671^{\prime} \mathrm{E}$; 6 June 2012; $20.37 \mathrm{~m}$ depth; dissected in slide.

\section{TYPE LOCALITY}

Near Ashdod, Israel, Mediterranean.

\section{ETYMOLOGY}

Dedicated to Bella Galil.

\section{DIAGNOSIS}

Gn1 carpus and merus lengthened. Gn2 propodus palm concave and sculptured with incisions and spines, strong determining spine on palmar corner. P6, 7 basis rounded, posterodistal corner lengthened; merus distally lengthened but not much widened. $\mathrm{U}_{2}$ rami unequal. $\mathrm{U}_{3}$ peduncle subequal ramus. $\mathrm{T}$ spinose.

\section{DESCRIPTION}

Length: $0.7-1 \mathrm{~mm}$.

Head: Eyes. Normally rounded. Mouthparts. Md palp absent. Antennae: A2 somewhat $>$ A1.

Peraeon: Gn1 basis long and narrow, ratio $\mathrm{l}: \mathrm{b}=6$; merus ratio $l: b=4-5$, subequal in length to lengthened triangular carpus, propodus palm smooth, all articles poorly spinose.
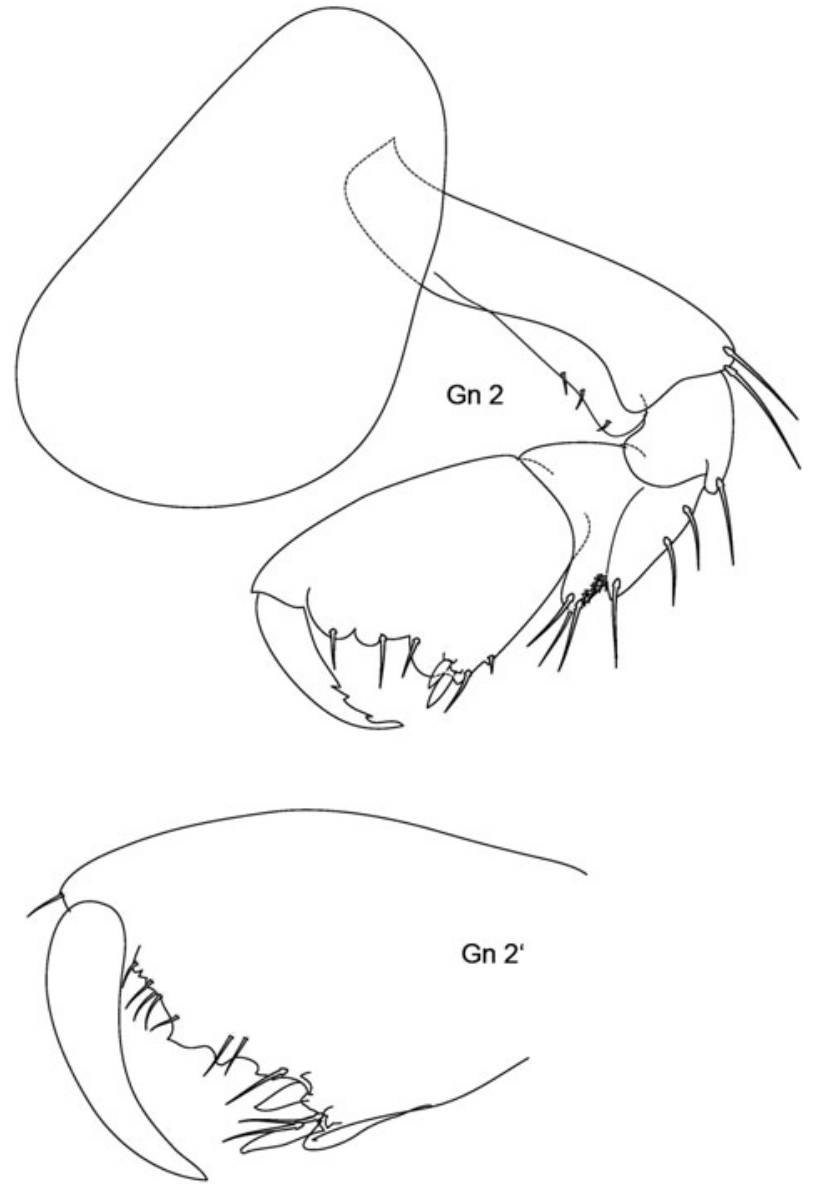

Fig. 2. Stenothoe bella sp. nov.: $\mathrm{Gn} 2=\operatorname{gnathopod} 2$ in two different magnifications.

Cx2 relatively narrow, ratio $1: b=13: 8$, distally regularly rounded. Gn2 basis much stronger than basis Gn1, distally widened; merus not reaching end of triangular carpus; propodus palm about as long as remaining hind margin, strongly sculptured with irregular excavations, palmar corner about $120^{\circ}$, beset with two strong spines.

$\mathrm{Cx} 4$ triangular, about as long as wide.

Peraeopods with long dactyli, ratio propodus: dactylus $=$ 3:2 or 4:3; merus in all peraeopods overlapping carpus, but never reaching end of carpus. $\mathrm{P} 6,7$ basis posteriorly regularly rounded, posterodistal corner lengthened.

Pleon: $\mathrm{U}_{1}$ peduncle and subequal rami of similar length. $\mathrm{U}_{2}$ length of peduncle between the one of the strongly unequal rami. $\mathrm{U}_{3}$ peduncle robust with 3 marginal spines, peduncle $<$ ramus art $1+$ art2, ramus art2 straight and acute, longer than art 1.

Telson: Triangular, flappable, with two marginal spines.

Female: No sexual difference observed.

\section{ECOLOGY}

This species was found together with Bathyporeia sp., Perioculodes sp., Tanaissus microthymus Bird \& Bamber, 2009 and Apseudopsis mediterraneus (Bacescu, 1961) on sandy-muddy bottoms. Depth range is between $12.4 \mathrm{~m}$ and $37.34 \mathrm{~m}$. 


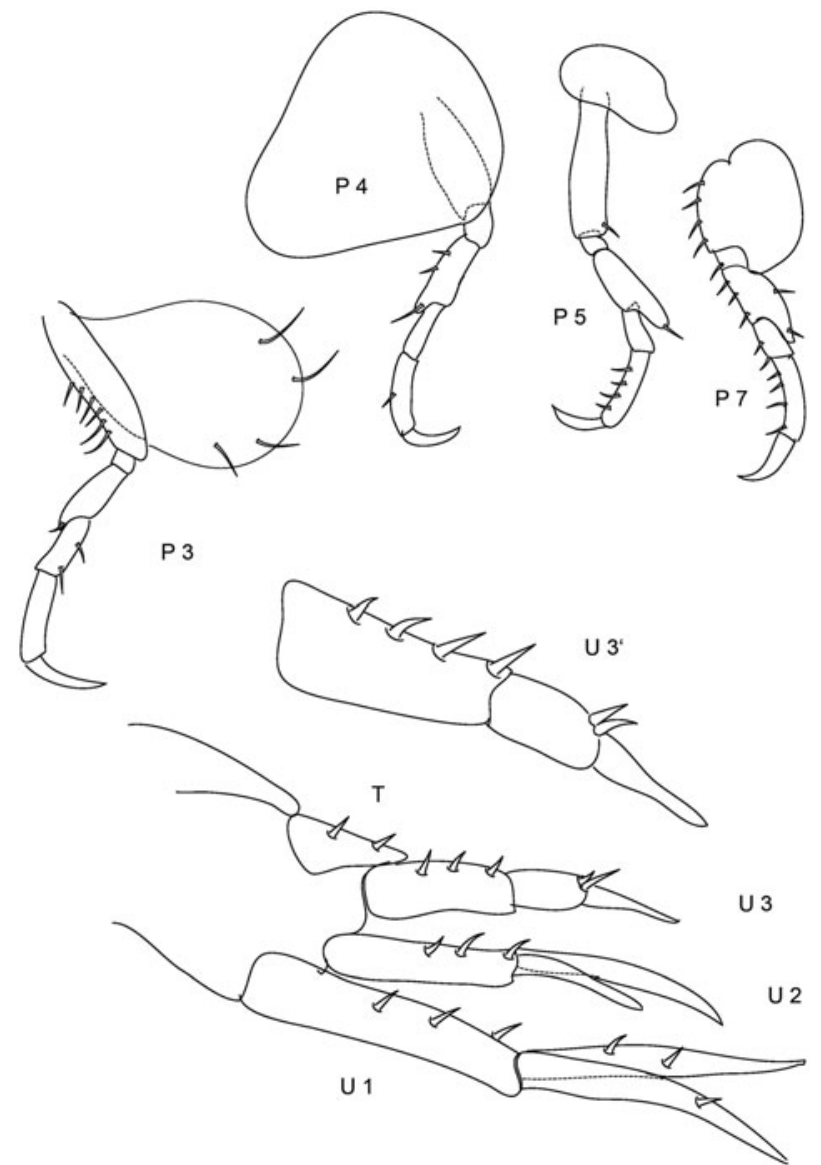

Fig. 3. Stenothoe bella sp. nov.: $\mathrm{P}_{3}-7$ peraeopods; $\mathrm{U}_{1-3}=$ uropods; $\mathrm{T}=$ telson.

\section{DISTRIBUTION}

Mediterranean coast of Israel.

\section{REMARKS}

This species is clearly a dweller of the interstitium; it bears a similarity to Stenothoe antennulariae Della Valle, 1893 as well as Stenothoe bosphorana Sowinsky, 1898 und Stenothoe cavimana Chevreux, 1908. From the latter, it is distinguished by a spinose telson and a longer Gn1 carpus, from the former, especially, by the very different $\mathrm{Gn} 2$ propodus, but also by the much more robust $\mathrm{U}_{3}$.

\section{Stenothoe levantina sp. nov.}

Figures $4 \& 5$

\section{MATERIAL EXAMINED}

Holotype: one specimen $1.1 \mathrm{~mm}$ from sample $2 \mathrm{~B}$, Ala $32.90025^{\circ} \mathrm{N} 35.06735^{\circ} \mathrm{E}$; 25 February 2011; $12.4 \mathrm{~m}$ depth. Slide in Faure together with additional material coded as MZPA-AMPH-N_0oo7.

ADDITIONAL MATERIAL

One specimen $0.7 \mathrm{~mm}$ from same sample as above, $32.90025^{\circ} \mathrm{N}$ $35.06735^{\circ} \mathrm{E} ; 25$ February 2011; $12.4 \mathrm{~m}$ depth. Slide in glycerine.

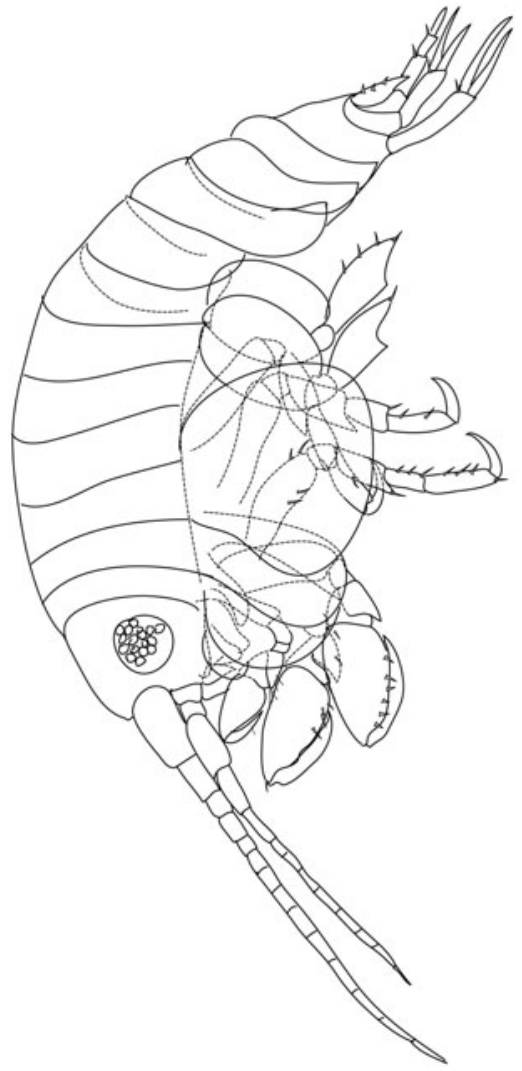

Fig. 4. Stenothoe levantina sp. nov.: habitus of the specimen with $0.7 \mathrm{~mm}$ length.

TYPE LOCALITY

Near Ashdod, Israel, Mediterranean.

\section{ETYMOLOGY}

Living in the far East of the Mediterranean, the epitheton should allude to 'Levante', allegoric for sunrise or East in general.

\section{DIAGNOSIS}

Gn1 carpus and merus short. Gn2 without sculpture, dactylus about as long as entire propodus. P6, 7 basis rounded, posterodistal corner lengthened; merus strongly widened and acutely lengthened. $\mathrm{U}_{2}$ rami unequal. $\mathrm{U}_{3}$ peduncle subequal ramus. $\mathrm{T}$ spinose.

\section{DESCRIPTION}

Length: $0.7-1.1 \mathrm{~mm}$.

Head: Eyes round. Mouthparts: Md clearly asymmetrical. Mx2 plates sitting upon each other, very much reduced. Mxp: outer plate vanishing. Antennae: A1 $>$ A2.

Peraeon: $\mathrm{Gn} 1$ basis long and narrow, merus and carpus carpus not much lengthened, propodus with smooth palm without palmar corner, dactylus reaching nearly end of propodus hind margin.

$\mathrm{Cx} 2$ broad, anterior margin semicircular, posterior margin slightly concave. Gn2 basis distally widened, merus distally acutely pointed, carpus triangular, propodus palm smooth, beset with some short setae and one stronger spine near end of dactylus.

Peraeopods: $\mathrm{P}_{3}-\mathrm{P}_{7}$ merus lengthened, in $\mathrm{P} 6,7$ also widened. P6, 7 basis similarly rounded. 




$\operatorname{Mxp}$
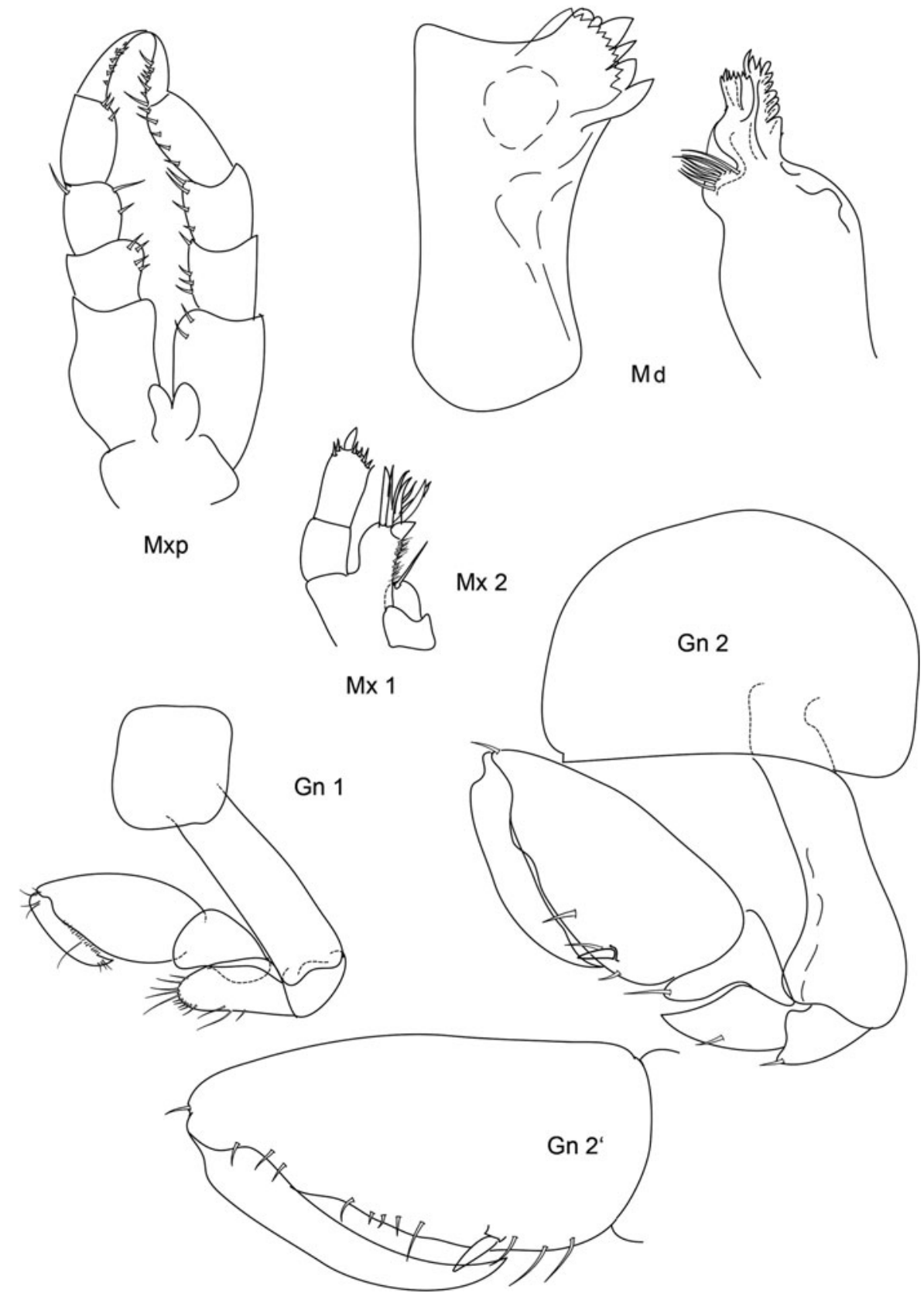

Fig. 5. Stenothoe levantina sp. nov.: $\mathrm{Mxp}=$ maxilliped; $\mathrm{Mx} 1,2=\operatorname{maxillae} 1,2 ; \mathrm{Md}=$ mandible; $\mathrm{Gn} 1,2=$ gnathopods $1,2$.

Pleon: $\mathrm{U}_{1}$ peduncle subequal to subequal rami, scarcely spinose. $\mathrm{U}_{2}$ rami clearly unequal, scarcely spinose. $\mathrm{U}_{3}$ peduncle subequal to rami, poorly spinose.

Telson: Flappable, triangular, with three marginal spines.

Female: Not known.

\section{ECOLOGY}

Similar to Stenothoe bella.

\section{DISTRIBUTION}

Mediterranean coast of Israel.

\section{REMARKS}

This species also seems to live between sand grains. While the body shape, the antennae, peraeopods and uropods are very similar to the species described above, it differs in its $\mathrm{Gn}_{1}$ and Gn2, which are similar to each other here, not sculptured and with carpus and merus short.

World-wide, this species is similar to Stenothoe cavimana Chevreux, 1908, but differs in the unsculptured Gn2 and spinose telson. It certainly belongs to the group of Stenothoe elachista, Stenothoe pieropan and Stenothoe mandragora, all in Krapp-Schickel, 1996 and all found among sand or mud, probably licking the surface of the grains; but it differs by the shape of its peraeopods and its spinose telson.

\section{ACKNDWLEDGEMENTS}

The authors are grateful to Dr Bella Galil, Senior Scientist at the Israel National Institute of Oceanography for Oceanographic and Limnological Research (IOLR), for 
making this material available for our study; and to Davide Iaciofano for technical assistance at the University of Palermo.

\section{REFERENCES}

Boeck A. (1871) Crustacea Amphipoda Borealia et Arctica. Forhandlinger $i$ Videnskabs-Selskabet i Christiania 1870, 83-280.

Chevreux E. (1908) Description de deux nouvelles espèces d'Amphipodes des parages de Monaco. Bulletin de l' Institut océanographique, Monaco 5(133), 1-8.

Dana J.D. (1852) Conspectus crustaceorum quae in orbis terrarum circumnavigatione, Carolo Wilkes e classe Rei publicae Faederatae Duce, lexit et descripsit Jacobus D. Dana. Pars III (Amphipoda No. 1). Proceedings of the American Academy of Arts and Sciences 2, 210-220.

Della-Valle A. (1893) Gammarini del Golfo di Napoli. Fauna und Flora des Golfes von Neapel und der angrenzenden Meeres-Abschnitte 20, XI-948.

Krapp-Schickel T. (1996) New data on stenothoids (Crustacea, Amphipoda). Mitteilungen des Hamburger Zoologischen Museums 93, 91-116.

Krapp-Schickel T. (2011) New Antarctic stenothoids sensu lato (Amphipoda, Crustacea). European Journal of Taxonomy 1, 1-17. http://dx.doi.org/10.5852/ejt.2011.2

Krapp-Schickel T. (2015) Minute but constant morphological differences within members of Stenothoidae: the Stenothoe gallensis group with four new members, keys to Stenothoe worldwide, a new species of Parametopa and Sudanea n. gen. (Crustacea, Amphipoda). Journal of Natural History, doi: 10.1080/00222933.2015.1021873. Available at: http://dx.doi.org/10.1080/00222933.2015.1021873.

Latreille P.A. (1802) Histoire naturelle, générale et particulière des crustacés et des Insectes, Vol. 1-4. Paris: Dufart.

Latreille P.A. (1816) Nouveau dictionnnaire d'histoire naturelle, appliquée aux arts, à l'agriculture, à l'èconomie rurale et domestique, à la médicine etc., 2nd edn. Coll. 1. Paris: Detreville.

Sowinsky W. (1898) Les Crustacés supériours (Malacostraca) du Bosphore d'après les materiaux recueillis par $\mathrm{Mr}$ le $\mathrm{Dr}$ A.A. Ostrooumow. I. Amphipoda et Isopoda [in Russian]. Mémoires de la Société des naturalistes de Kiev 15, 447-518.

and

Watling L. (1989) A classification system for crustacean setae based on the homology concept. In Felgenhauer B.E., Walting L. and Thiestle A.B. (eds) Crustacean issues, Vol. 6. Rotterdam: A.A. Balkema, pp. 15-26.

\section{For the Correspondence Address:}

\section{T. Krapp-Schickel}

Forschungsmuseum A. Koenig

Adenauerallee 160

D-53113 Bonn

Germany

email: traudl.krapp@uni-bonn.de 